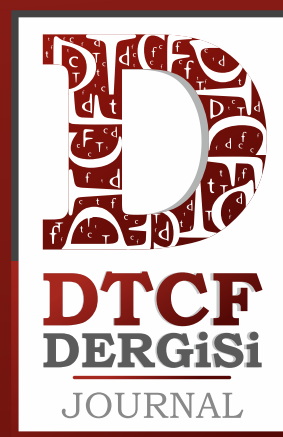

Makale Bilgisi

Gönderildiği tarih: 1 Mart 2021

Kabul edildiği tarih: 8 Mayıs 2021

Yayinlanma tarihi: 24 Haziran 2021

Article Info

Date submitted: 1 March 2021

Date accepted: 8 May 2021

Date published: 24 June 2021

Anahtar sözcükler

Yenilenebilir Enerji; Latin Amerika;

Brezilya; Hidrolik Enerji; Etanol

Keywords

Renewable Energy; Latin America;

Brazil; Hydroenergy; Ethanol

DOI: $10.33171 /$ dtcfjournal.2021.61.1.13

\section{YENİLENEBİLİR ENERJİNIN ÖNEMİ VE LATİN AMERİKA COĞRAFYASINDAKİ YERİ: BREZİLYA ÖRNEĞİ}

THE IMPORTANCE OF RENEWABLE ENERGY AND ITS PLACE IN LATIN AMERICAN GEOGRAPHY: THE EXAMPLE OF BRAZIL

\section{Ali DURUKAN}

Yüksek Lisans Öğrencisi, Ankara Üniversitesi, Sosyal Bilimler Enstitüsü, Latin Amerika Çalışmalar, drkn8681@yahoo.com

\section{Mutlu YILMAZ \\ Doç.Dr., Ankara Üniversitesi, Dil ve Tarih-Coğrafya Fakültesi, Coğrafya Bölümü, yilmazm@ankara.edu.tr}

$\ddot{O} z$

Enerji kaynaklan bir yandan dünyamızın en büyük ihtiyact diğer yandan da en büyük sorunlarından biridir. Dünyada fosil enerji kaynaklarının eşit olmayan dağılımı nedeniyle üretim, sevkiyat ve ticaret süreçlerinde ülkeler arasinda çeşitli problemler yasanabilmektedir. Aynca bu enerji kaynaklarinin üretiminden tüketimine kadar geçen süreç içinde ciddi çevre sorunlar ortaya çıkmaktadır. Yenilenebilir enerjiler dünyanın her yerinde bulunan, tükenmez ve çevre dostu kaynaklardır. Bu enerjilerin yaygınlaşmasıyla birlikte ülkeler arasında fosil enerji kaynaklara bağlı olan çatıșmaların azalması beklenmektedir. Ekonomik açıdan fosil yakıtların kullanımı günümüzde daha fazla tercih ediliyor olsa da gelișen teknolojiyle ilerleyen yıllarda yenilenebilir enerji kaynaklarinın kullanımı fosil yakıtlara kıyasla daha ekonomik hale gelecektir. Bu çalışmada ilk olarak dünyanın enerji görünümü ve yenilenebilir enerji kaynaklan açılklanmıştır. Müteakibinde ise gelişmekte olan ekonomileri ve önemli potansiyelleri ile Latin Amerika'nın yenilenebilir enerji kaynaklar verilmiştir. Son olarak örnek ülke Brezilya'nın yenilenebilir enerji kaynaklar ve mevcut üretim durumu açıklanmıștır: Latin Amerika coğrafyasının en büyük ülkesi olan Brezilya; hidrolik, rüzgâr, güneş ve biyoküle enerjileri potansiyeli bakımından dünyada ilk sirada gelen ülkeler arasinda yer almaktadır. Yenilenebilir enerji kaynaklar açısından zengin potansiyele sahip olan Brezilya, gün geçtikçe daha çok bu kaynaklara yönelmektedir.

\section{Abstract}

Energy resources are one of the biggest needs of our world on the one hand, and one of the biggest problems on the other. Due to the unequal distribution of fossil energy resources in the world, various problems may occur between countries in production, shipping and trade processes. In addition, serious environmental problems arise in the process from the production to the consumption of these energy resources. Renewable energy sources are inexhaustible and environmentally friendly. They can be found all over the world. In this respect, it will have important contributions in reducing conflicts between countries. Although the use of fossil fuels is economically more preferred today, the use of renewable energy sources will become more economical than fossil fuels in the coming years with the developing technologies. In this study, the energy outlook of the world is presented first. Then, renewable energy sources are explained. Subsequently, renewable energy potential of Latin America, which has got a very big potential with its developing countries, and renewable enrgy sources in Brasil, as an example country, are examined. Brazil, the largest country in the Latin American geography, is among the top countries in the world in terms of hydro, wind, solar and biomass energies potential. Brazil is turning to these resources more and more day by day.

\title{
1.Giriş
}

Günümüzde meydana gelen teknolojik gelişmeler, enerjiye olan ihtiyac1 artırırken enerji kaynaklarına bağımlılığı da kaçınılmaz hale getirmiștir. Tarih boyunca enerji ihtiyacını değişik yollardan gidermeye çalışan insanoğlu, özellikle yerleşik hayata geçip tarım toplumlarını oluşturmaya başlayınca bunu daha farklı kaynaklardan karş1lama arayışına girmiştir. Çünkü göçebe toplumlarda enerjiye olan talep az iken, yerleşik hayata geçilmesi ve tarımsal üretim ile birlikte enerji gereksinimi daha fazla olmuştur (Gülgün, Keskin ve Ünal Ankaya 20). 
18.yy.da yaşanan Endüstri Devrimi, insanlık tarihine enerji gereksinimi açısından yeni bir ivme kazandırmıştır. Endüstri Devrimi'nin hâkim enerji kaynağı kömürdür. 20.yy'ın başında icat edilen içten yanmalı motor ise, enerji tüketiminde petrol çağını başlatmıştır. Çünkü içten yanmalı motorlarda güç kaynağı olarak kullanılan petrol, enerji verimliliği açısından kömüre göre daha uygundur. Çağımızın enerji kaynağı olarak bilinen petrol günümüzde ulaşım sektörü dışında farklı alanlarda da ham madde kaynağıdır. Petrol; ilaç, solvent, gübre, pestisit ve plastik yapımı başta olmak üzere pek çok alanda kullanılmaktadır (Elmas 31). II. Dünya Savaş1 sonrasında ise nükleer enerji ve doğalgaz dünyada kullanımı hızla artan fosil enerji kaynakları olmuştur.

Geçtiğimiz yüzyılın sonlarına doğru yoğun bir şekilde tüketilmeye başlayan fosil kaynaklar, başta iklim dengesinin bozulması olmak üzere çok fazla soruna neden olmuştur (Özel ve Kılıç 137). Literatürde küresel 1sınma olarak adlandırılan ve fosil kaynakların aşırı tüketilmesi sonucu ortaya çıkan iklim değişikliği sorunu eğer önlem alınmazsa önümüzdeki yıllarda daha da büyük problemlere neden olacaktır. Yaşanan bu sorun, meteorolojik kökenli pek çok doğal afet artışına neden olmaktadır (Demirbaş ve Aydın 167). Çevresel anlamda bir diğer olumsuzluk ise fosil kaynakları çıkarmak için doğal peyzajın tahrip edilmesidir. Ayrıca fosil yakıt kaynaklı doğaya karışan katı, sıvı ve gaz atıkları çevreyi kirletmektedir (Doğan 38). $\mathrm{Bu}$ sorunların daha fazla yaşanmaması için fosil yakıtlara alternatif olarak yenilenebilir enerji kaynakları önerilmektedir. Görülen çevresel felaketler ve fosil enerji kaynaklarının temininde yaşanan ekonomik ve politik sorunlar insanları çevreyle dost enerji kaynağı bulma süreçlerine yöneltmiştir. Bu arayış bilimden politikaya pek çok alanı etkilemeye başlamış, hatta dünya liderleri yaptıkları zirvelerde (Stockholm 1972, Rio 1992, Kyoto 2005 ve Paris 2015), çevre konularını ele alırken alternatif enerji kaynaklarını tartışmaya başlamışlardır. Bu süreçte, bilim insanları "Yenilenebilir enerji kaynaklarını daha etkin ve çevre dostu olarak nasıl kullanabiliriz?" sorusunun cevabını bulmak için çalışmalarını sürdürmektedir.

Yaşanan son gelişmeler 1şığında dünya, enerji kaynakları tüketimi yönü ile yeni bir döneme girmiştir. Bu dönemde genel enerji tüketimi içinde yenilenebilir enerji kaynaklarının payı her geçen gün artmaktadır. Latin Amerika ülkeleri, zengin yenilenebilir enerji kaynakları potansiyelleri ve bunların genel enerji tüketimi içindeki paylarının yüksekliği ile ön plandadır. Latin Amerika'da yer alan ülkeler açısından bu potansiyeli kullanmak ve fosil enerji kaynaklarında olan dışa 
bağımlılı̆̆ bitirip alternatif ve milli enerji kaynaklarına yönelmek çok önemlidir (Jamel).Çünkü petrol bakımından dışa bağımlı ve gelişmekte olan ülkelerin ithalat miktarları içinde en büyük payı, enerji giderleri oluşturmaktadır. Nitekim 1973 yılında yaşanan petrol krizi, enerjide dışa bağımlılığın bir ülkenin ekonomisi açısından ne kadar önemli olduğunu göstermiştir. Arap-İsrail Savaşı nedeniyle Arap ülkelerinin uyguladığı petrol ambargosu dünyada petrol fiyatlarını yaklaşık 4 kat artırmış ve petrol ithal eden ülkelerin ekonomileri ağır yara almıştır (Öztürk ve Saygın 4). Bu kriz ve son yıllarda dünyanın yaşamış olduğu fosil enerji kaynaklı çevresel sorunlar sonrası bazı ülkeler, klasik anlamda kullanılan rüzgâr, güneş, biyokütle, jeotermal, hidrojen enerjisi, denizel enerji gibi enerji kaynaklarının modern kullanım şekillerine yönelmişlerdir.

İkincil kaynakların kullanıldığı ve derleme niteliğinde olan bu çalışmada Latin Amerika özelde ise Brezilya'nın yenilenebilir enerji potansiyeli ve tüketimi incelenmiştir. Latin Amerika coğrafyası başta hidrolik olmak üzere güneş, rüzgâr ve biyokütle potansiyeli bakımından oldukça zengindir. $\mathrm{Bu}$ zengin potansiyelin kullanılması her geçen gün artmaktadır ve Latin Amerika bu yönü ile dünyanın diğer bölgelerinden farklı bir özellik göstermektedir.

\section{Dünyanın Enerji Durumu}

Dünyada enerji tüketimi, önemli bölgesel değişikliklere karşın ekonomik büyüme, teknolojik gelişme ve nüfus artışına paralel olarak sürekli bir artış eğilimi içindedir (Tablo 1). Önümüzdeki yıllarda da enerji tüketimindeki bu artışın devam edeceği öngörülmektedir. Ancak, enerji talebindeki bu artış her ülkede aynı seviyede olmamaktadır. 1990'lı yıllardan sonra özellikle gelişmiş ülkelerin enerji talebinde bir yavaşlama gözlenirken, gelişmekte olan ülkelerin talepleri her geçen gün büyümeye devam etmiştir. Bu nedenle, önümüzdeki 30 yıllık süreçte OECD ülkelerinin enerji talebi \% 17 oranında artarken, OECD dışı ülkelerde ise bu artışın \% 90 civarında olması beklenmektedir. Bu grupta, Çin ve Hindistan gibi fazla nüfuslu, hızlı bir şekilde ekonomik büyüme gerçekleştiren ülkeler bulunmaktadır (Y1lmaz 34).

Dünya birincil enerji kaynakları tüketimi 1980 yılında 7.224 Mtep iken, 2000 yılında 10.034 Mtep'e, 2018 yılında 14.315 Mtep'e ulaşmıştır. Bu tüketim içinde $\% 31,4$ ' lük pay ile petrol ilk sirada gelir. Onu kömür $(\% 26,7)$, doğalgaz $(\% 22,9)$, biyokütle $(\% 9,5)$, nükleer enerji $(\% 5)$, hidrolik enerji $(\% 2,5)$ ve diğer yenilenebilir enerji kaynakları (\%2) takip etmektedir (Tablo 1). Bu değerler içinde fosil yakıtların payı \%86, yenilenebilir enerji kaynaklarının payı ise, \%14'tür. Uluslararası Enerji 
Ajansı'nın yapmış olduğu çalışmalara göre, dünyada birincil enerji kaynakları tüketiminin 2035 yılında 18.677 Mtep'e ulaşması tahmin edilmektedir ("Key World Energy Statistics”). Bu öngörülere göre, 2035 yılında birincil enerji kaynakları içinde kömür tüketimi \%29,6 lık pay ile ilk sıraya yükselirken petrol ise \%27'lik pay ile ikinci sıraya gerileyecektir. Ayrıca doğalgaz ve diğer yenilenebilir enerji kaynaklarının genel enerji tüketimi içerisindeki oranları da artmaya devam edecektir. Bu süreçte nükleer enerji, biyokütle enerjisi ve hidrolik enerjinin payları ise azalacaktır.

Tablo 1. Dünya birincil enerji kaynakları tüketimi (Mtep)

\begin{tabular}{|c|c|c|c|c|c|c|c|c|}
\hline & \multicolumn{2}{|l|}{1980} & \multicolumn{2}{|l|}{2000} & \multicolumn{2}{|l|}{2018} & \multicolumn{2}{|l|}{2035} \\
\hline Kaynak türü & Mtep & $\%$ & Mtep & $\%$ & Mtep & $\%$ & Mtep & $\%$ \\
\hline Petrol & 3107 & 43 & 3649 & 36,4 & 4501 & 31,4 & 5053 & 27,1 \\
\hline Kömür & 1788 & 24,8 & 2295 & 22,9 & 3821 & 26,7 & 5523 & 29,6 \\
\hline Doğalgaz & 1235 & 17 & 2088 & 20,8 & 3273 & 22,9 & 4380 & 23,5 \\
\hline Nükleer & 186 & 2,6 & 675 & 6,7 & 709 & 5 & 1019 & 5,5 \\
\hline Hidrolik & 148 & 2,1 & 225 & 2,3 & 361 & 2,5 & 460 & 2,5 \\
\hline Biyokütle & 748 & 10,4 & 1045 & 10,4 & 1357 & 9,5 & 1741 & 9,3 \\
\hline Diğer Yenilenebilir & 12 & 0,1 & 55 & 0,5 & 293 & 2 & 501 & 2,7 \\
\hline Toplam & 7224 & 100 & 10034 & 100 & 14315 & 100 & 18676 & 100 \\
\hline
\end{tabular}

$\mathrm{Bu}$ genel enerji tablosu içinde Çin, Hindistan ve Ortadoğu ülkeleri gibi gelişmekte olan ülkelerde, fosil enerji kaynaklarının ağırlığı devam ederken başta Avrupa Birliği ülkeleri olmak üzere gelişmiş ülkelerin yenilenebilir enerji kaynaklarına olan yatırımları ve genel enerji tüketimi içindeki payları daha fazla artacaktır.

\section{2.a. Geleneksel Enerji Kaynaklar1}

Günümüzde fosil kaynaklar olarak nitelendirdiğimiz petrol, doğalgaz, kömür ve nükleer enerji, birincil enerji kaynakları tüketiminde hala en büyük paya sahiptirler (Grafik 1). Bu grafiğe göre geleneksel yakıtların payı, 2000 yılında \%87,4 iken 2018 yılında bu oran \%86'ya gerilemiştir. Aynı yıllar arasında, yenilenebilir 
enerji kaynaklarının kullanımında artış gözlemlenmiştir. Ancak bu genel enerji tüketimi içinde henüz çok büyük bir orana karşılık gelmemektedir.

Geleneksel enerji kaynakları olarak adlandırılan fosil kaynakların ömrü çok fazla değildir. Yapılan projeksiyonlara göre dünyada petrolün 50-60 yıl, doğalgazın 60-70 yıl, maden kömürünün 120 y1l, linyit kömürünün ise 220 y1l sonra tükeneceği öngörülmektedir (Kömür ve Enerji Raporu 5). Fosil enerjilerin yakın gelecekte tükenecek olması ülkelerin alternatif enerjiler arayıp bulmaları için en önemli motivasyon kaynaklarından biridir.

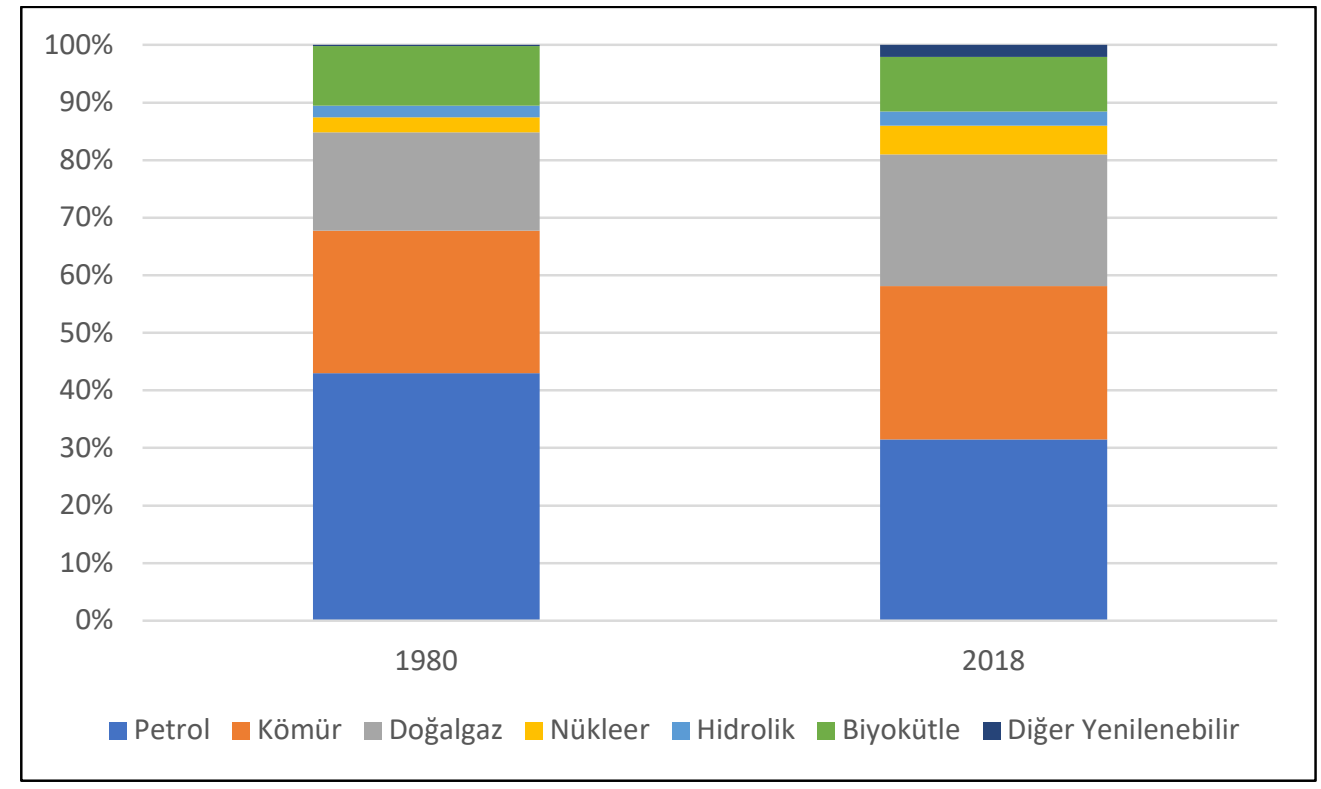

Grafik 1. Dünyada 1980 ve 2018 yıllarında tüketilen enerji kaynaklarının oransal bölünüşü

Petrol, sanayide ham madde kaynağı olmaya başladığı dönemden, günümüze kadar ülkeler arasında paylaşım mücadelesinin yaşandığ1 en önemli enerji kaynağıdır. Bu enerji kaynağında rezervler itibarıyla en büyük pay \% 48,3 ile $(836,1$ milyar varil) Ortadoğu ülkelerine aittir. Daha sonra sırasıyla \%18,8 lik pay ile Latin Amerika (325,1 milyar varil), \%13,7'lik pay ile Kuzey Amerika (236,7 milyar varil) ülkeleri gelmektedir (“Petrol”). Görüldüğü gibi petrol rezervlerinin 3/4’ü Ortadoğu ve Latin Amerika ülkelerinde bulunmaktadır. Tipkı petrol gibi dünyada doğalgaz rezervleri de asimetrik dağılmıştır. Doğalgaz rezervlerinin \%38,4'ü (75,5 trilyon metreküp) Ortadoğu ülkelerinde, \%33,9’u Avrasya'da (66,7 trilyon metreküp), $\% 16,5$ ’i Afrika/Asya Pasifik ülkelerinde (32,5 trilyon metreküp) bulunmaktadır (“Doğalgaz"). 
Dünya kömür rezervleri yaklaşık 892 milyar ton büyüklüğündedir. $\mathrm{Bu}$ rezervlerin 403 milyon tonu antrasit ve bitümlü kömür oluşturmaktadır. Geri kalan kısmı ise alt bitümlü kömür ve linyit kömürüne aittir. Rezervler itibarıyla ABD (237 milyar ton), Rusya (157 milyar ton), Çin (114 milyar ton) ön siralarda gelmektedir (Kömür Sektör Raporu 15).

\section{2.b. Yenilenebilir Enerji Kaynaklar1}

1973 yılında yaşanan ve küresel çapta bir etkiye yol açan petrol krizi, dünyayı ekonomik yönden büyük ölçüde sarsarak petrole olan bağımlılığın sorgulanması ve yenilenebilir enerji kaynaklarının gündeme gelmesine neden olmuştur. Ancak daha aktif bir şekilde bu fikrin uygulanmas1 2000'li yılları bulmuştur (Yıldırım ve Nuri 109). Yenilenebilir enerji kaynakları, günümüz dünyasında fosil yakıtların yerini alabilecek en büyük adaydır. Bu kaynakların fosil yakıtlara göre en önemli avantajı tükenmez olmalarıdır. Ayrıca üretimden tüketime kadar olan süreç içerisinde fosil kaynaklara göre daha çevre dostu olmaları büyük avantajdır. Bunun yanında genellikle kaynak olarak daha geniş bir coğrafyada bulunurlar. Bu bağlamda fosil yakıtlarda olan enerji bağl1lığ1, yenilenebilir enerji kaynakları için aynı etkiyi göstermemektedir.

Günümüzde ticari anlamda kullanılan yenilenebilir enerji kaynakları ve bunların mevcut enerji üretimindeki durumunu şu şekilde sıralayabiliriz:

- Güneş Enerjisi: Güneş elektrik veya termal enerji şeklinde kullanılabilecek karbon salınımına neden olmayan yenilenebilir bir enerji kaynağıdır. Bu enerji kaynağı, günümüzde yaygın olarak kullanım şekli güneşten gelen 1şınların fotovoltaik (PV) güneş enerjisi panelleri aracilığ1 ile elektriğe dönüştürülmesi şeklindedir (Akova 32). Bu enerji kaynağının kullanım kolaylığı, potansiyelinin fazla olması, yenilenebilir ve çevre dostu olması hızlı bir şekilde yaygınlaşmasına neden olmuştur. Günümüzde bu kaynak elektrik üretiminde temel kaynaklardan biri olma yolundadır. 2020 yılına gelindiğinde dünyada toplam elektrik enerjisi kurulu gücün içinde 707.494 MW'lık kısmı güneş enerjisinden sağlanmıştır (“Solar Energy”).

- Rüzgâr Enerjisi: Atmosferde yaşanan basınç farkları sonucu rüzgâr oluşur. Oluşan bu rüzgâr, türbinler sayesinde aldıkları mekanik enerjiyi elektrik enerjisine çevirirler. Çevreye herhangi bir zararlı atık yaymayan temiz bir enerji kaynağıdır. Özellikle son y1llarda gelişen teknolojiler ve birim maliyetlerinin düşmesiyle birlikte hızlı bir şekilde kullanılmaya başlanmıştır. 2020 yılı itibarıyla 34.362 MW'ı offsore (aç1k deniz), 698.909 MW'1 karalarda olmak üzere dünya üzerindeki kurulu güç 733.271'MW'a ulaşmıştır (“Wind Energy”). 
- Hidroelektrik Enerjisi: Suyun iki noktası arasındaki potansiyel enerji fark1 kullanılarak elektrik enerjisi üretilir. Suyun sağladığı mekanik enerji elektrik enerjisine dönüştürülür. Hidroelektrik santraller barajlı ve nehir tipi olarak ikiye ayrılır. 2020 y1lında dünyada hidroelektrik santrallerin kurulu gücü 1.209.531 MW’a ulaşmıştır ("Hydropower”). Latin Amerika ülkeleri ve Brezilya bu enerji türü açısından oldukça büyük bir potansiyele sahiptir.

-Biyokütle Enerjisi: Biyokütle; bitkiler, ağaçlar ve tarımsal ürün ve atıkların oluşturduğu bütün organik maddeleri tanımlayan bir terim olarak esasen fotosentez ile güneş enerjisinin toplandığı ve depolandığı ortamlardır. Bu enerji türü, karbondioksit, su ve güneş enerjisi kullanan bitkilerin toplamıdır. Biyoenerji, sıvı biyoyakıt (genellikle enerji zengini ürünlerden elde edilen), atık (evsel atıklar dâhil), katı biyokütle (odun, odun kömürü ve diğer biyokütle maddeleri) ve gaz (biyokütle çürümelerinden elde edilen) formlarında elde edilir. Biyokütle enerjisi günümüzde hem geleneksel hem de modern yöntemlerle kullanılmaktadır. Geleneksel anlamda genellikle gelişmekte olan ülkelerde ısınma ve yemek pişirme amacıyla yaygın olarak kullanılmaktadır. Modern anlamda ise, başta elektrik üretimi olmak üzere biyodizel, biyoetanol gibi ürünlerin edesinde kullanılır. Modern yöntemlerle elde edilen biyokütle enerjisi kurulu gücü 2020 y1lında 126.654 MW'a ulaşmıştır ("Bioenergy”). Araştırmanın konusu olan Brezilya etanol üretimi için kullanılan şeker kamışı ve etanol üretiminde ilk sırada gelmektedir. Bu yönü ile önemli bir kaynak ülkesidir.

- Jeotermal Enerji: Yer kabuğunda biriken termal enerjidir. Antik Romalilar ve Çinliler banyo, pişirme ve ısınma amaçlı bu enerjiyi kullanmışlardır. Günümüzde ise jeotermal enerjinin yüksek 1sı değerleri kullanılarak elektrik üretimi yapılmaktadır. Atmosferik olaylara bağlı olmadığı için güneş ve rüzgâr enerjilerinden farklı olarak devamlı enerji sağlanabilmektedir. Bu yüzden verimliliği daha yüksektir. Dünya üzerinde daha sınırlı alanda bulunan bu kaynağın kurulu gücü 2020 y1lında 10.050 MW olmuştur ("Geotermal energy”).

- Okyanus Enerjisi: Denizlerdeki ve okyanuslardaki gel-git olaylarından kaynaklanan dalga hareketlerini kullanarak mekanik enerjiyi elektrik enerjisine dönüştürmeyi amaçlar. Bu enerji türünden faydalanmak istenirken kıyı ekolojisinin güvenliği, gemicilik ve balıkçılık sektörlerinin durumu gibi etkenler göz önünde bulundurulmalidir. 


\section{Latin Amerika'da Yenilenebilir Enerji Kaynakları Potansiyeli}

Ülkeler, sahip oldukları enerji kaynaklarını önceliğe alan bir enerji tüketim stratejisi belirlemektedirler. Bu nedenle enerji kaynaklarının tüketiminde bölgeler ve ülkeler ölçeğinde farklılıklar gözlemlenmektedir. 2019 yılında bölgelerin enerji tüketim oranlarına bakıldığında fosil temelli kaynakların tüketiminin tüm bölgelerde ilk sırada geldiği görülmektedir (Grafik 2). Latin Amerika'yı kapsayan Orta ve Güney Amerika ülkelerinde yenilenebilir enerji kaynakları diğer bölgelere göre pozitif yönde ayrılmaktadır. Bunun en önemli nedeni bölgenin çok zengin hidroelektrik potansiyele sahip olmasıdır. Latin Amerika Avrupa ile birlikte hidrolik dışındaki diğer yenilenebilir enerji kaynakları tüketiminde de bölgesel anlamda ilk siralarda gelmektedir.

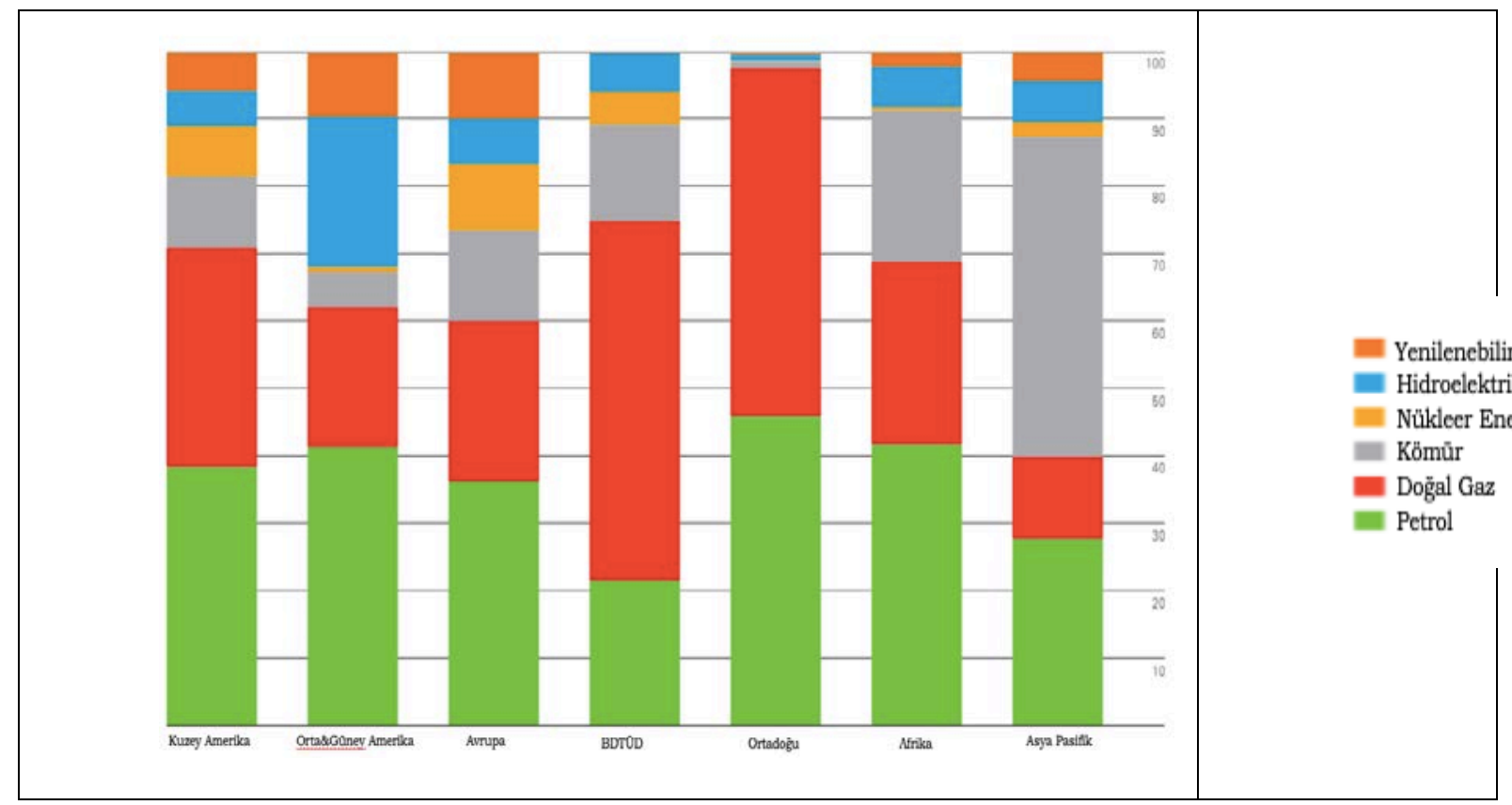

Grafik 2. 2019 Y1lı Bölgesel Enerji Tüketimi (\%)

Dünyada genel anlamda elektrik üretiminde fosil enerjiler ön planda yer almasına karşın Latin Amerika'da yenilenebilir enerji kaynaklarının payı oldukça yüksektir (Grafik 3). 2019 yılında dünyada üretilen 27004,7 TWh elektriğin \%73,9'u fosil kaynaklardan sağlanmıştır. Yenilenebilir enerji kaynaklarının payı \%26,1 seviyesindedir ("Statistical Review of World Energy"). Ancak yenilenebilir enerji kaynaklarının Latin Amerika elektrik üretimi içindeki payı \%67,6'dır. Görüldüğü gibi Latin Amerika'da elektrik enerjisi üretiminde yenilenebilir enerji kaynaklarının payı çok büyüktür. Brezilya'da ise, elektrik enerjisi üretimi içinde yenilenebilir enerji kaynaklarının payı \%82,6 gibi daha da yüksek bir değere sahiptir. 


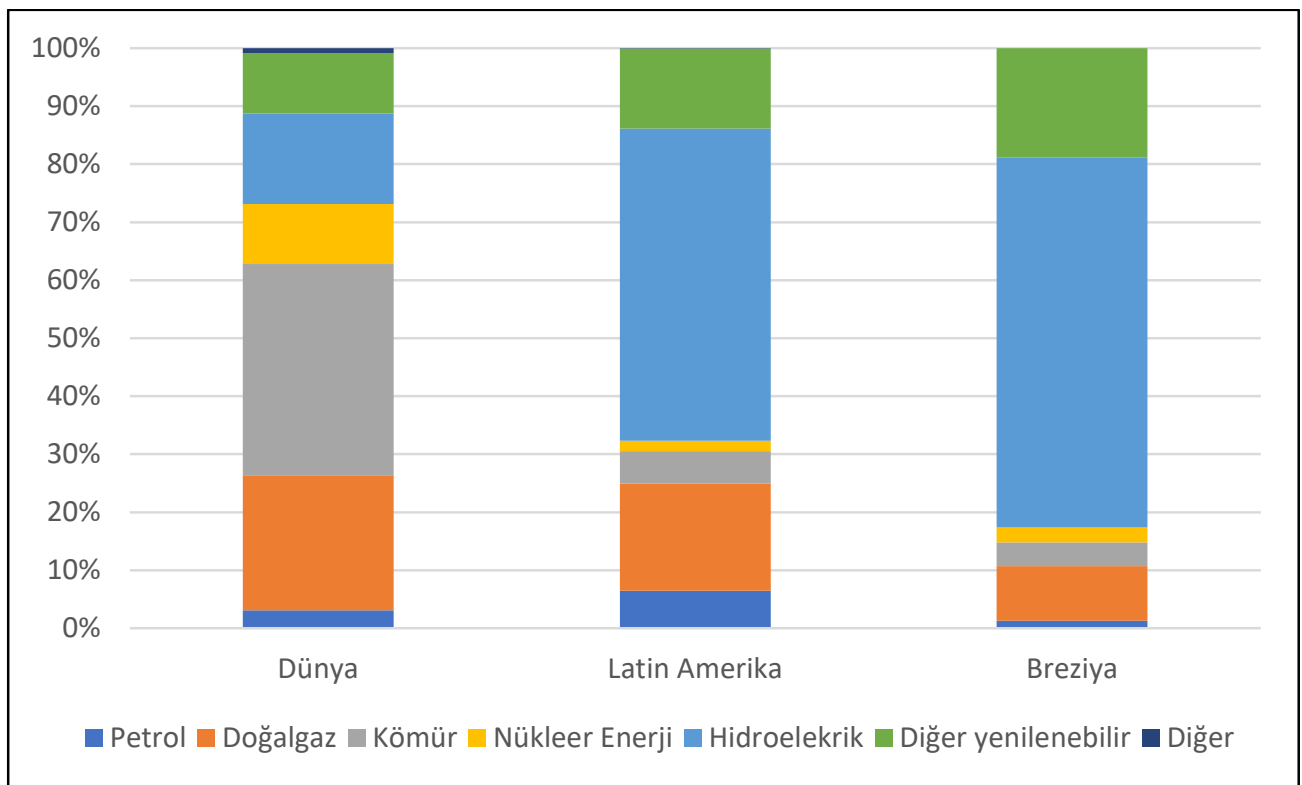

Grafik 3. Dünya, Latin Amerika ve Brezilya'da elektrik üretiminin kaynaklara göre oransal bölünüşü (2019)

Latin Amerika özelde ise Brezilya elektrik enerjisi üretiminde dünyanın tam tersi bir yapıya sahiptir. Bu bölgede özellikle hidrolik potansiyelin bol bulunmas1 elektrik üretiminde bunu yoğun bir şekilde kullanmasına neden olmuştur. Küresel 1sınma açısından düşünüldüğünde Latin Amerika ülkelerinin elektrik üretimlerinde daha çevreci kaynakları kullanmakta olduklarını göstermektedir.

Dünya genelinde 2015 yılı itibariyle yenilenebilir enerjiye olan yatırımlar incelendiğinde bazı enerji türleri ve ölçekler yönünden Latin Amerika ülkelerinin ön sıralarda geldiği görülmektedir (Karagöl ve Kavaz 12) (Tablo 2). Örneğin, Latin Amerika ülkeleri olan Honduras ve Uruguay yenilenebilir enerji ve yakıtlara olan birim GSYIH başına yatırım açsından dünya sıralamasında 2. ve 3. durumdadır. Aynı yıl itibarıyla dünyada jeotermal kapasite artışında Meksika, Türkiye ve ABD'nin ardından üçüncü sırada gelmektedir. Hidrolik enerji kapasite artışında Brezilya Çin'den sonra ikinci sırada yer alır. Brezilya, güneş kolektörleri kapasite artışında dünyada 3., rüzgâr enerjisi kapasite artışında ise 4. sırada yer almıştır. Bunların yanında dünyanın en büyük şeker kamışı üreticisi olan Brezilya, biyodizel ve etanol yakıt üretiminde ABD'den sonra dünyada ikinci sırada yer almıştır. Bu yönü Brezilya, farklı yenilenebilir enerji kaynakları kapasite artışı ve üretimi bakımından dünyada ilk sırlarda gelmektedir. 
Tablo 2. Yenilenebilir enerji alanında yatırım, kapasite artışı ve üretim bakımından ilk beş ülke (2015)

\begin{tabular}{|l|l|l|l|l|l|}
\hline & \multicolumn{1}{|c|}{1} & \multicolumn{1}{|c|}{2} & \multicolumn{1}{|c|}{4} & 5 \\
\hline Yenilenebilir Enerji ve Yakıtlara Olana & Moritanya & Honduras & Uruguay & Fas & Jamaika \\
\hline Jeotermal enerji kapasite artışı & Türkiye & ABD & Meksika & Kenya & Almanya/ \\
\hline Hidrolik enerji kapasite artışı & & & & & Japonya. \\
\hline Güneş kollektörü kapasite artışı & Çin & Brezilya & Türkiye & Hindistan & Vietnam \\
\hline Rüzgâr enerjisi kapasite artışı & Çin & Türkiye & Brezilya & Hindistan & ABD \\
\hline Biyodizel üretimi & ABD & Brezilya & Almanya & Arjantin & Fransa \\
\hline Etanol yakıt üretimi & ABD & Brezilya & Çin & Kanada & Tayland \\
\hline
\end{tabular}

\section{Brezilya'nın Yenilenebilir Enerji Kaynakları Potansiyeli ve Tüketimi}

Brezilya, 8,5 milyon km²' lik yüz ölçümü ve 210 milyonluk nüfusu ile Latin Amerika'nın en büyük ülkesidir. Ülke aynı zamanda kıtanın en fazla enerji üretim ve tüketim oranlarına sahiptir. Brezilya, enerji ihtiyacını hem geleneksel enerji kaynakları hem de yenilenebilir enerji kaynaklarıyla karşılamaya çalışmaktadır. Ülkede 2019 yılında 12,4 EJ birincil enerji kaynağ1 tüketimi olmuştur. Bu tüketim içerisinde en büyük pay \%38,1'lik oranı ile petrole (4,73 EJ) ait iken onu \%28,7 ile hidroelektrik enerji (3,56 EJ) takip etmiştir. Brezilya'da, birincil enerji kaynakları tüketiminde hidroelektrik enerjinin petrolden sonra ikinci sırada olmasının sebebi dünyanın en fazla su taş1yan akarsu kaynağı olan Amazon Nehri'nin burada bulunmasıdır. Daha sonra sırasıyla \%16,3 ile diğer yenilenebilir kaynakları $(2,02$ EJ), \%10,4 ile doğalgaz (1,29 EJ), \%5,3 ile kömür (0,66 EJ) ve \%1.1 ile nükleer enerji (0,14 EJ) takip etmektedir("Statistical Review of World Energy”) (Grafik 4). 


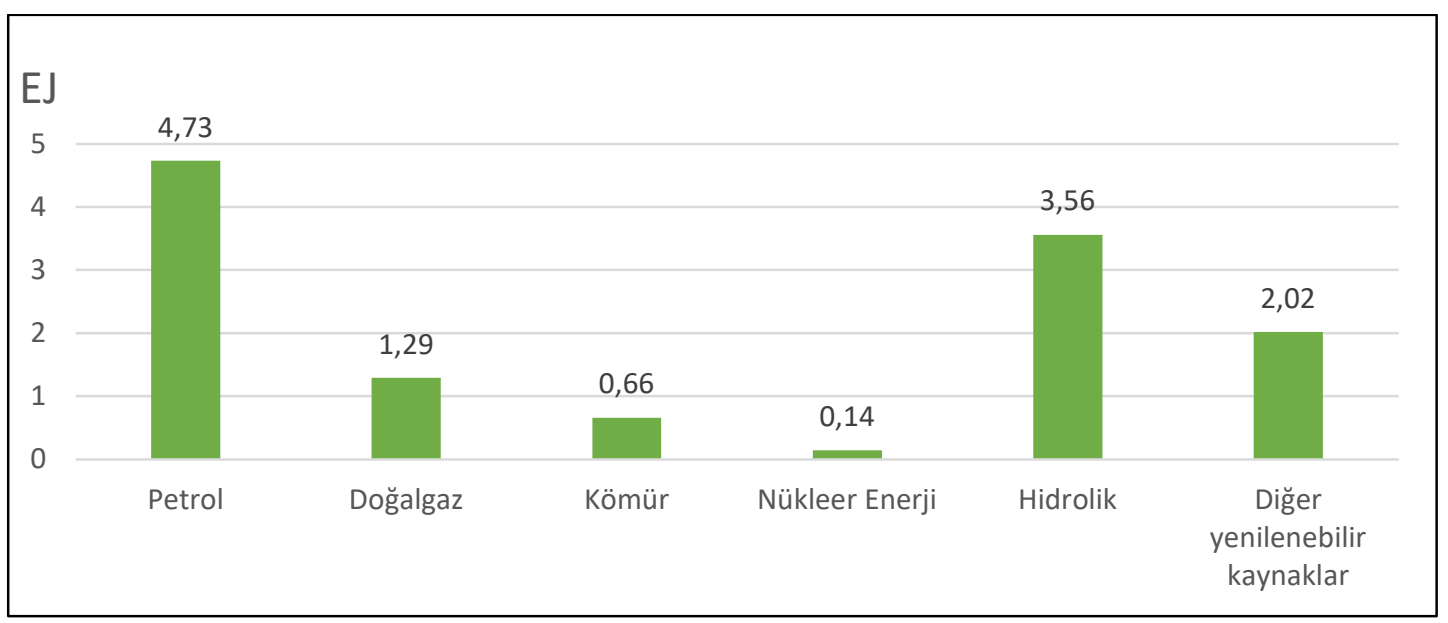

Grafik 4. Brezilya'da birincil enerji kaynakları tüketimi (2019)

Brezilya'da birincil enerji kaynaklarının tüketiminde 1965 yılından günümüze, petrol ve hidrolik kaynaklarının hep ön planda olduğu görülmektedir (Grafik 5). Nitekim 1965 y1lında petrolün pay1 \%66 iken 2019 y1lında \%38'e gerilemiştir. Ancak hala petrol birincil enerji kaynakları tüketiminde ilk sırada yer almıştır. Hidrolik kaynakların birincil enerji kaynakları tüketimi içindeki payı, 1965 y1lında \%26,3 iken, 2019 y1lında \%28,7'ye yükselmiştir. Genel olarak geçmişten günümüze Brezilya'da birincil enerji kaynakların tüketiminde fosil kaynakların payı azalmış, yenilenebilir enerji kaynaklarının payı ise artmıştır. Ancak fosil yakıtlar içerisinde sadece doğalgazın payında bir artış söz konusudur. Özellikle son yıllarda rüzgâr, biyokütle ve güneş enerjisinin paylarının arttığı da görülmektedir. Bu durum Brezilya'nın fosil enerji kaynaklarından yenilenebilir enerji kaynaklarına doğru bir geçiş süreci içinde olduğunun göstergesidir (Grafik 5).

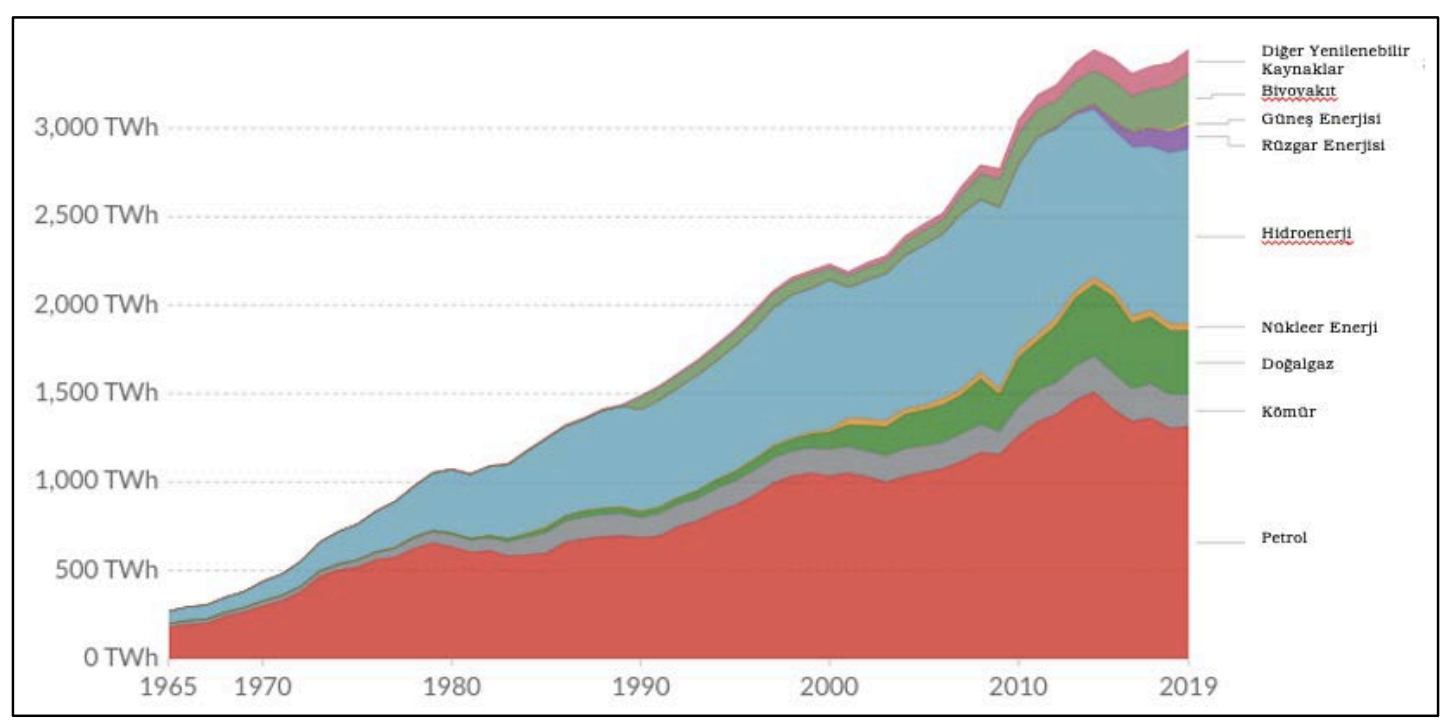

Grafik 5. Brezilya'da birincil enerji kaynakları tüketiminin yıllara göre değişimi (1965-2019) 
Brezilya'da elektrik enerjisi üretiminde yenilenebilir enerji kaynakları içinde en büyük pay daha öncede bahsedildiği gibi hidrolik kaynaklara aittir. Ülkede 2010 yılında hidrolik kaynaklara bağlı kurulu güç 80.703 MW iken, 2015 yılında 91.650 MW'a ve 2019 yılında 109.092 MW'a ulaşmıştır (Grafik 6). Bu değer dünyadaki hidrolik kurulu gücünün \%8,3'ü gibi oldukça büyük bir payını oluşturmaktadır (“Renewable Capacity Highlights").

Hidrolik enerjinin Brezilya enerji üretiminde büyük payı vardır. Ülke Latin Amerika'nın en büyük hidrolik kurulu gücüne sahiptir. Sektör toplam Brezilya elektrik enerji kapasitesinin \%64'ünü oluşturur ve elektrik talebinin dörtte üçünden fazlasını karşılar ("Brazil Statistics"). Hidrolik enerjinin ülke hatta bölge ekonomisinde ne kadar büyük yer tuttuğunu bu rakamlar göstermektedir. Özellikle Amazon Havzası'nın zengin su kaynakları Brezilya'nın hidrolik enerji üretimindeki öz güvenini artırmaktadır. Brezilya-Paraguay sınırında yer alan 14.000MW kapasiteye sahip Itapu Baraj1, 11.233 MW kapasiteli Belo Monte Baraj1 ve 8300 MW kapasiteye sahip Tucuruí Barajı ülkenin ve dünyanın en büyük hidroelektrik santralleri arasında yer almaktadır ("Belo Monte HydroPower Project”).

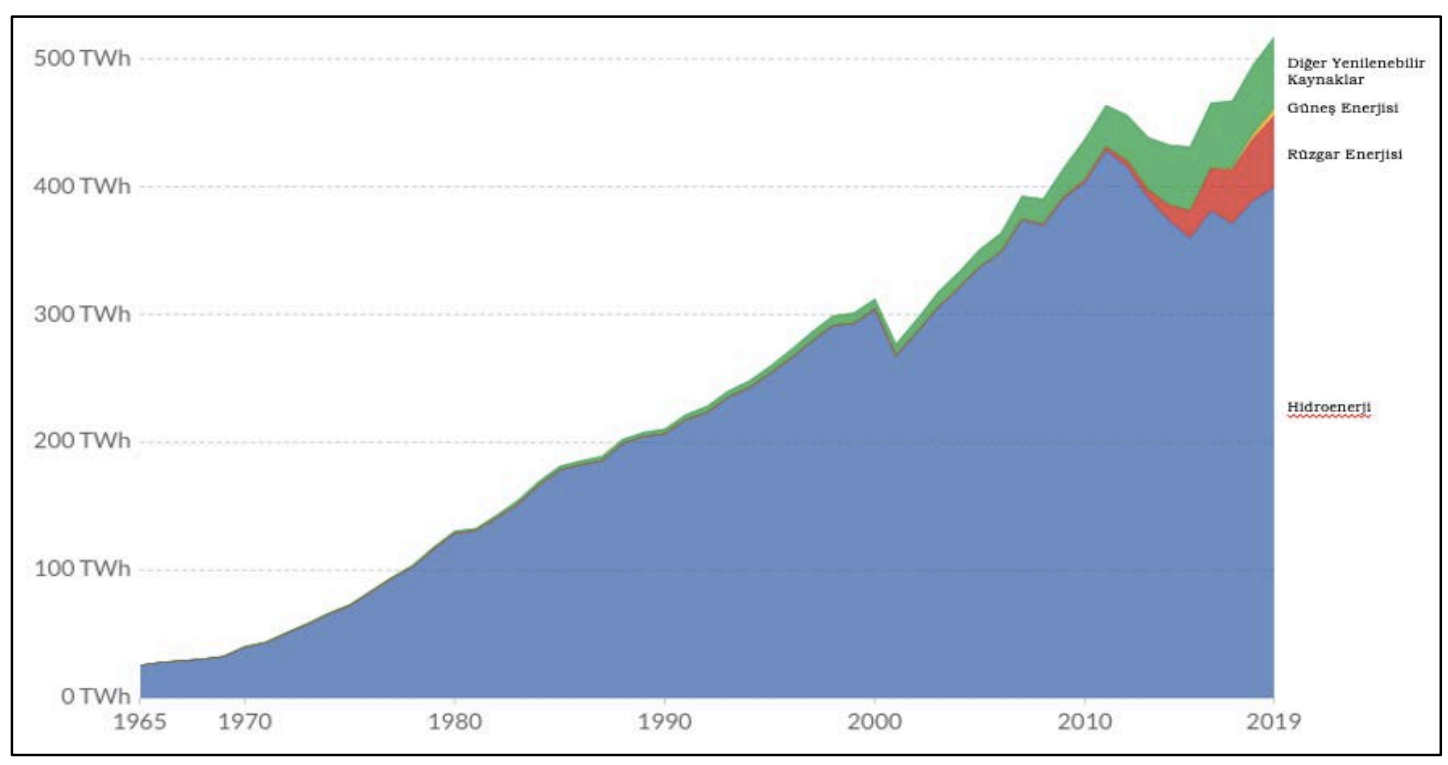

Grafik 6. Brezilya'da y1llara göre yenilenebilir enerji kaynaklarında elektrik üretimi (1965-2019)

Elektrik enerjisi tüketimi ekonomik gelişmenin en temel göstergelerinden biridir ve enerji sektöründe elektrik enerjisinin kritik bir önemi bulunmaktadır. İkincil enerji kaynaklarından olan elektrik enerjisinin üretiminde Brezilya'da yenilenebilir enerji kaynaklarının payı, dünyadaki pek çok ülkenin aksine daha fazladır. Geçmişten günümüze ülke elektriğinin \%80’i yenilenebilir kaynaklarından 
sağlanmaktadır. Geliştirilen projeksiyonlar, bu durumun ileriki yıllarda daha da artarak devam edeceğini göstermektedir (Grafik 7).

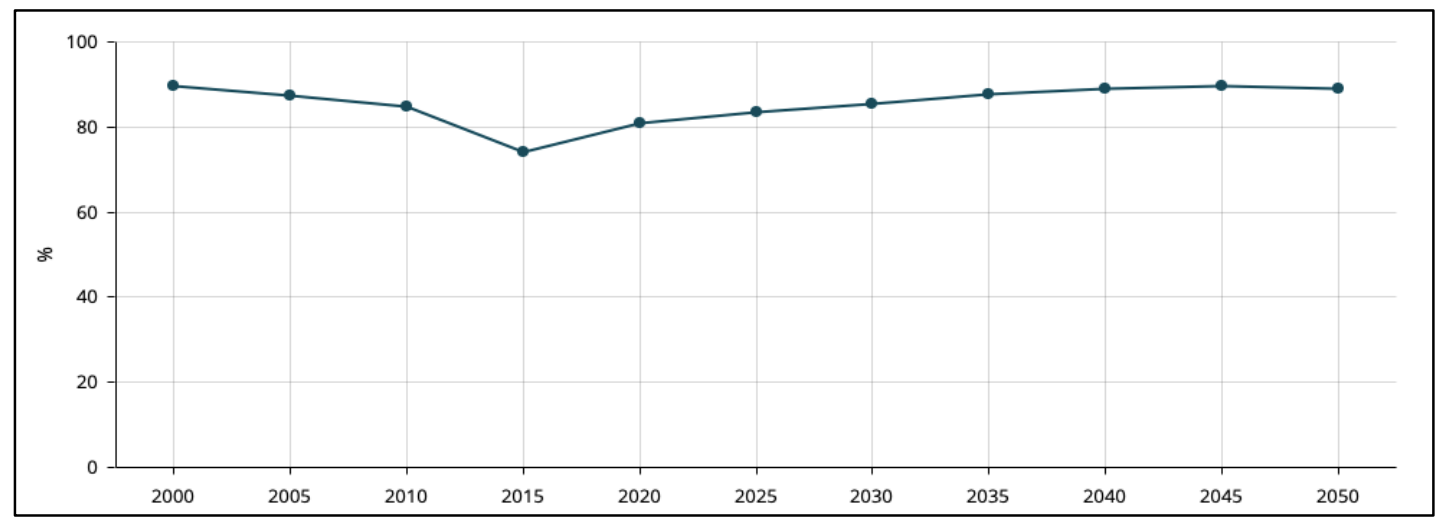

Grafik 7. Brezilya'da elektrik üretiminde yenilenebilir enerjinin pay1 (20002050).

Brezilya'da rüzgâr enerjisi kurulu gücü her geçen yıl artmaktadır. Ülkede 2010 yılında rüzgâr enerjisine bağlı olan kurulu güç 927 MW iken, 2015 yılında 7633 MW'a, 2019 yılında ise 15364 MW'a çıkmıştır. Brezilya yüz ölçümü itibariyle geniş bir alana sahiptir ve diğer yenilenebilir enerji kaynakları gibi rüzgâr potansiyeli bakımından da dünyada önde gelen ülkelerin başında gelmektedir. Ülkede 2018 y1lı itibariyle rüzgâr santrallerinden 48489 GWh elektrik enerjisi üretilmiştir. Görüldüğü gibi rüzgâr enerjisi elektrik üretiminde her geçen gün payını artırmaktadır. Brezilya Rüzgâr Enerjisi Birliği tarafından çıkarılan 15.06.2019 tarihli Infovento haber bültenine göre, ülkede 12 eyalette 7.738 işleyen rüzgâr türbiniyle 637 rüzgâr çiftliği bulunmaktadır. Brezilya'da Kuzey Amerikalı GE, merkezi İspanya'da bulunan Simens-Gamesa, yerel firma WEG(WEGE3) ve Alman Nordex (Acciona) gibi önemli enerji firmalarının rüzgâr enerjisi yatırımları bulunmaktadır ("Wind Energy in Brazil...").

Brezilya'nın matematik konumu gereği güneş enerjisi potansiyeli oldukça yüksektir. Dünyada görülen gelişmelere paralel olarak son yıllarda Brezilya'da da güneş enerjisinden elektrik üretiminde bir ivme gözlenmektedir. Ülkede 2010 y1lında güneş enerjisi kurulu gücü 2 MW, 2015 yılında 27 MW ve 2019 y1lında 2485 MW değere ulaşmıştır ve bu y1l itibariyle güneş panellerine dayalı elektrik üretimi 3987 GWh olmuştur.

Biyokütle enerjisi, Brezilya'nın en önemli enerji kaynaklarından biridir. Bu enerji kaynağı geleneksel olarak ateşin bulunuşundan günümüze bilinen ve kullanılan bir enerji türüdür. Modern anlamda biyokütlenin kullanımı ise, günümüze çok yakın bir zamanda olmuştur. Biyokütle enerjisi; modern anlamdaki 
uygulamalarda biyogaz, biyoetanol, diyodizel, biyometanol, biyoyağ gibi enerji kaynaklarına dönüşmektedir. Yaygın kullanımı ise daha çok biyodizel, biyoetanol ve biyogazdır. Brezilya 2019 yılında dünyadaki 124.026 MW'lık biyokütle kurulu gücü içinde 14.992 MW ile $(\% 12,1)$ büyük bir paya sahiptir. Bu değeri ile dünyada Çin'den sonra ikinci sırada gelmektedir.

Brezilya büyük oranda biyokütle hammaddesi olarak kullanılan şeker kamış1 üretiminde dünyada ilk sirada gelmektedir.2019 yılında yapılan 1,949 milyar tonluk dünya şeker kamışı üretiminin \%38,6's1 (715 milyon ton) Brezilya tarafından karşılanmıştır. Aynı yıl itibariyle Hindistan 405 milyon ton $(\% 20,7)$, Tayland 131 milyon ton $(\% 6,6)$ ve Çin 108 milyon ton (\%6) üretim değerleriyle Brezilya'nın arkasından gelmektedir ("Sugar cane production quantity"). Diğer önemli üreticiler ise sirasıyla; Pakistan, Meksika ve Kolombiya'dır (Grafik 8).

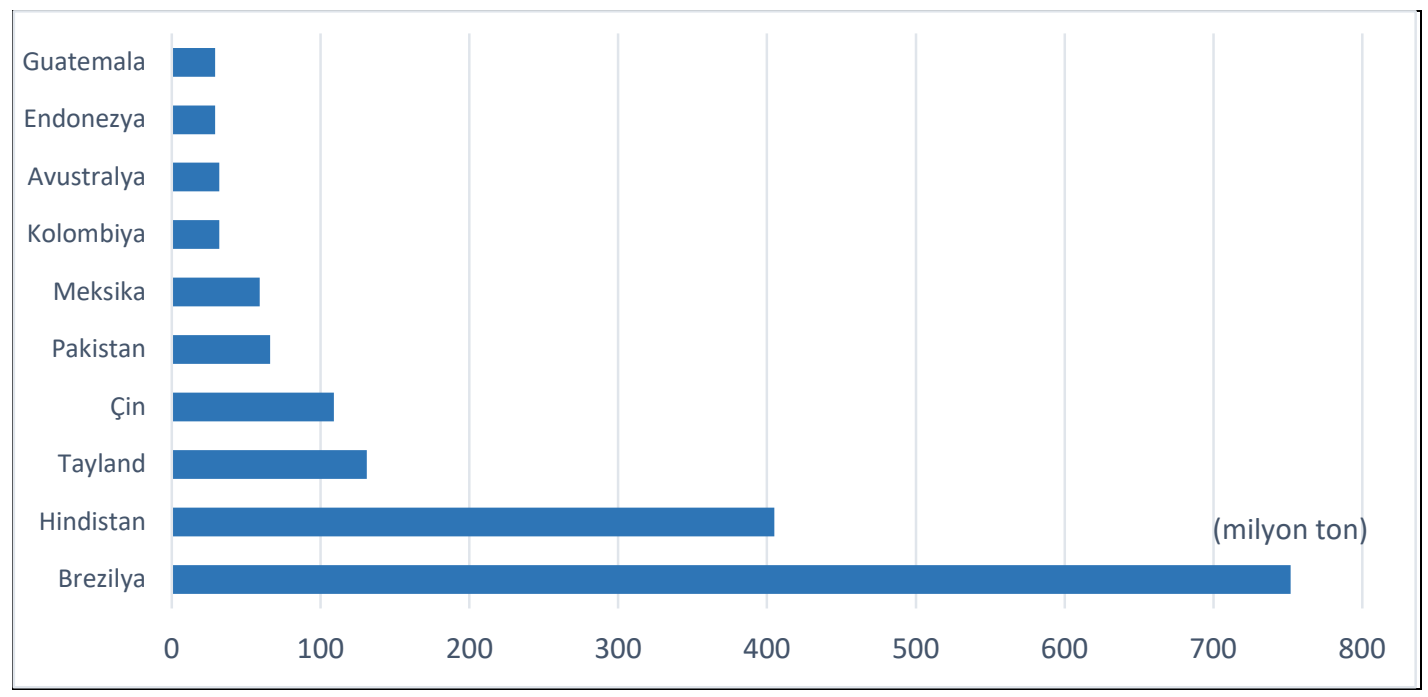

Grafik 8. Dünya en fazla şeker kamışı üretimi yapan ülkeler (2019)

Sahip olduğu büyük potansiyel nedeniyle Brezilya biyokütle enerjisi konusunda ciddi atılımlar yapmaktadır (Alves). Ülke özellikle şeker kamışı ve misırdan elde edilen "alkol/etanol" ile standart dizel yakıtına belli miktarda bitkisel yağ karıştırılarak elde edilen biyodizel üretiminde dünyada ilk sıralarda gelmektedir. 2018 y1lında dünyada üretilen etanol 28.670 milyon galon etanolün \% 56's1 (16100 milyon galon) ABD'de, \%28'i (7950 milyon galon) Brezilya'da üretilmiştir (“Ethanol Industry Outlook 7”). (Grafik 9). 


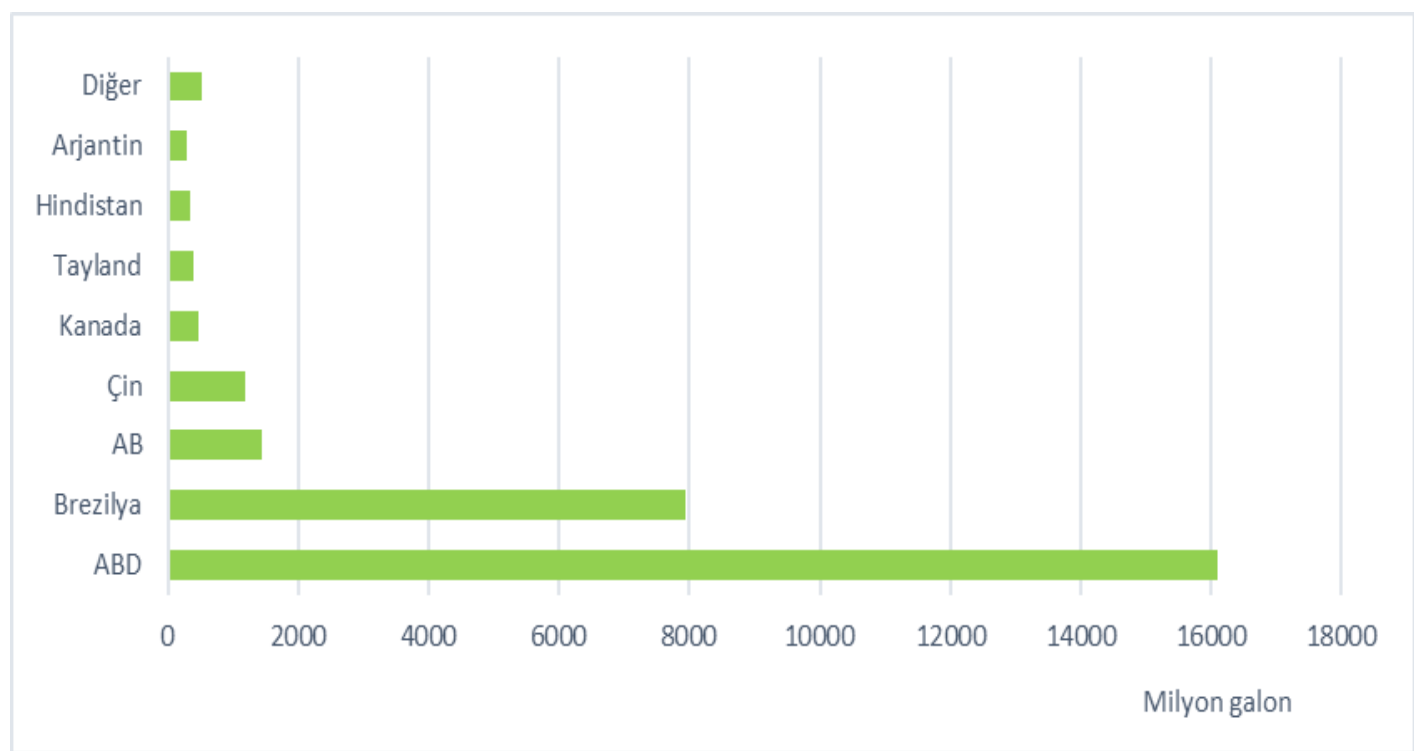

Grafik 9. Ülkelere Göre Etanol Üretimi (2018)

Dünyada etanol üretiminde önde gelen ülkelerden olan Brezilya, şeker kamışını ham madde olarak kullanmaktadır. Brezilya'da milli yakıt türü olarak etanol üretim projesi1975 yılında başlatılmıştır ve 2000'li yılların başından itibaren etanol kullanımı hız kazanmıştır (Uludüz). Etanol araçlarda yakıt olarak kullanılarak çevrenin korunmasında fayda sağlamaktadır. Yaklaşık \%25 oranında yakıtta harmanlama sağlayan Brezilya etanolü araç yakıtı olarak kullanması açısından örnek teşkil etmektedir ("Biyoyakıtlar İçin Kamu Politikaları-Dünya"). Biyoetanol benzin ile kullanıldığında oktan sayısını yükseltmekte ve içten patlamalı motorlarda kullanılması için bir avantaj sağlamaktadır (Ünlü 34). Yapılan çalışmalar neticesinde egzoz emisyonlarında; karışım oranındaki biyoetanol miktarı arttıkça $\mathrm{CO}, \mathrm{CO}_{2}$ ve $\mathrm{NO}_{\mathrm{x}}$ değerlerinde azalma belirlenmiş, araç yakıtlarında etanol katkısı petrole olan bağımlılığı da göreceli olarak azaltmıştır (Koçtürk ve Onurbaş Avcıoğlu 72).

Etanol üretiminin en önemli hammadde kaynağı olan şeker kamışı Brezilya tarım ve yakıt endüstrisinin önemli ürünlerinden biridir. Brezilya'da 1 milyondan fazla kişi şekerkamışı ve etanol üretiminde çalışmaktadır. Bu üretim kapasitesi Brezilya'nın etanol karışımlı yakıt kullanma politikasını desteklemektedir. Brezilya'da yıllık 3 milyon adet seviyesine ulaşan motorlu araç üretiminin yaklaşık 3/4'ü etanol ya da benzinle de çalışabilen, "Total Flex" olarak adlandırılan motorlu araçlardan oluşmaktadır (Türeyen). Flex araçlara sahip sürücüler ister benzin ister etanol isterlerse de benzin etanol karışımı yakıtlarla araçlarını kullanabilmektedirler. Bu tarz yakıt kullanımı tüketiciye daha ucuz yakıt arzına 
sebep olmakta, petrol bağımlılı̆̆ını azaltmakta, çevreye daha çok zarar veren fosil yakıt kullanımını düşürmekte ve sürücülere seçme esnekliği sağlayabilmektedir.

Brezilya'da etanol ve biyodizelin dağıtımı ve kontrolü Latin Amerika'nın en büyük piyasa değerine sahip ulusal petrol şirketi PETROBRAS tarafindan yapılmaktadır. PETROBRAS aracılığıyla Brezilya 2006 yılında petrolde kendi kendine yetebilen ülke haline gelmiştir (Türeyen).Etanol yakıtlar petrol bağımlılığını azaltma ve çevreye dost olma özelliğiyle geleceğin yakıt seçeneklerinden biri olma iddiasını güçlü bir şekilde korumaktadır.

\section{Sonuç}

Latin Amerika, kültürel ve ekonomik kaynaklarıyla dünyanın önemli bir parçasıdır. 19.yy.da bağımsızlığını kazanan Latin Amerika ülkeleri 20.yy ile birlikte siyasi birliklerini kurma çabalarına girmiş ve günümüz dünyasının vazgeçilmez siyasi figürleri haline gelmişlerdir. Sahip oldukları zengin yenilenebilir enerji kaynakları potansiyeli nedeniyle Latin Amerika ülkeleri diğer ülkelere göre daha fazla oranda yenilenebilir enerji kaynakları kullanmaktadırlar. Bölgede özellikle son yıllarda başta hidrolik enerji olmak üzere rüzgâr, güneş ve modern biyokütle kaynaklarına bağlı bir üretim-tüketim dengesi söz konusudur. Bu şekilde hem fosil enerji kaynakları yönü ile dışa bağımlılık azalmakta hem de çevre konusunda olumlu adımlar atılmaktadır.

Brezilya kıtanın en büyük nüfuslu ülkesi olarak en çok enerji üretim ve tüketimi yapan ülkedir. Ülke aynı zamanda yenilenebilir kaynaklar potansiyeli bakımından da kıtanın en zengin ülkesidir. Brezilya, hidroelektrik ve biyokütle potansiyeli ve üretim uygulamalarıyla dünyada söz sahibi olan ülkelerin başında gelmektedir. Hidrolik kaynaklar bakımında Brezilya tek başına diğer tüm Latin Amerika ülkelerinden daha çok enerji üretimi yapmaktadır. Bunun en önemli nedeni dünyanın en fazla su taşıyan akarsuyu olan Amazon Nehri ve kollarının büyük oranda Brezilya topraklarında bulunmasıdır. Ülkede Amazon dışında debisi yüksek pek çok akarsu bulunmaktadır.

Modern biyokütle ürünlerinden olan etanol üretiminde ABD'den sonra Brezilya \%28'lik payı ile ikinci sırada gelmektedir. Bunda Brezilya'nın1975'li yıllarda başlattığı ve etanolü milli bir yakıt türü olarak gördüğü proje oldukça etkili olmuştur. Ülkede üretilen şeker kamışını ham madde olarak kullanan Brezilya bu yönü ile önemli bir hamle yapmıştır. 
Rüzgâr enerjisi ve güneş enerjisinden elektrik üretiminde son yıllarda ivme kazanan Brezilya bu yönüyle de Latin Amerika ülkelerine öncülük etmektedir. Bu yatırımlar günümüz için sevindiricidir. Ayrıca kıtadaki diğer ülkelere örnek teşkil etmesi bakımından da önemlidir

\section{KAYNAKÇA}

Akova, İsmet. Enerji Kullanımındaki Değişimler. Ankara: Nobel Akademi, 2016.

Alves, Bruno. "Renewable Energy Generation Capacity in Brazil from 2010 to 2019."Statista.17 August 2020. Web. 4 Ocak 2021.

“Belo Monte HydroPower Project.”NS Energy. 2020. Web. 10 Ekim 2020.

"Bioenergy." Internationa Renewable Energy Agency (IRENA), 2020. Web. 23 Şubat 2021.

“Biyoyakıtlar İçin Kamu Politikaları-Dünya.”Arge7, 2016. Web.3 Haziran 2020.

"Brazil Statistics." International Hydropower Associaation, 2018. Web. 07 Ekim 2020.

Demirbaş, Maide ve Rozelin Aydın. “21. Yüzyılın En Büyük Tehdidi: Küresel İklim Değişikliği” Ecological Life Sciences. 15.1(2020):163-179.

“Doğalgaz” T.C. Enerji Bakanlığı. 2018. Web. 02 Şubat 2021.

Doğan, Mesut. "Enerji Kullanımının Coğrafi Çevre Üzerine Etkileri.” Marmara Coğrafya Dergisi 23 (2011):36-52.

Elmas, Makbule. "Petrol Endüstrileri ve Petrol İhraç Eden Ülkeler."Niğde Ömer Halisdemir Üniversitesi Sosyal Bilimler Enstitüsü Dergisi 1.3 (2019): 29-41.

"Ethanol Industry Outlook" Renewable Fuels Associations (RFA) 2019. Web. 02 Nisan 2021.

“Geotermal energy.”Internationa Renewable Energy Agency (IRENA), 2020. Web. 23 Şubat 2021.

Gülgün, Bahriye, Nazlı Keskin ve Funda Ünal Ankaya."Tarih Boyunca Bahçelerde Su Öğesinin Kullanımı."Ziraat Mühendisliği Dergisi 357 (2011):18-23.

Jamel, Abdul Latif. "Güç Potansiyeli Latin Amerika'da Yenilenebilir Enerji” Web. 12 Şubat 2021.

Karagöl, Erdal Tanas ve İsmail Kavaz. "Dünyada ve Türkiye'de Yenilenebilir Enerji." Seta Analiz 197 (2017):1-32. 
“Key World Energy Statistics.” (IEA), 2020. Web. 15 Şubat 2021.

Koçtürk, Derya ve Ayten Onurbaş Avcıŏlu. "Benzin Motorlarında Biyoetanol Kullanımının Ç̧evresel Etkilerinin Belirlenmesi”. Ankara Üniversitesi Çevrebilimleri Dergisi 4.2 (2012):65-74.

Kömür ve Enerji Raporu. Ankara: TMMOB Maden Mühendisleri Odas1, 2010. Web.15 Şubat 2021.

Kömür Sektör Raporu. Ankara: Türkiye Kömür İşletmeleri Kurumu, 2017. Web 3 Nisan 2021.

"Hydropower." Internationa Renewable Energy Agency (IRENA), 2020. Web. 22 Şubat 2021.

Özel, Mehmet ve Selim Kılıç. "Küresel Bir Sorun Olarak İklim Politikaları" I.Ü. Siyasal Bilgiler Fakültesi Dergisi 34 (2006):137-169.

Öztürk, Salih ve Selin Saygın. “1973 Krizinin Ekonomiye Etkileri ve Stagflasyon Olgusu." Balkan Sosyal Bilimler Dergisi 6.12 (2017):1-12.

“Petrol.” T.C. Enerji Bakanlığı. 2018. Web. 02 Şubat 2021.

"Renewable Capacity Highlights." Internationa Renewable Energy Agency (IRENA), 2020. Web. 29 Aralık 2020.

"Solar Energy." Internationa Renewable Energy Agency (IRENA), 2020. Web. 22 Şubat 2021.

“Statistical Review of World Energy." BP, 2020. Web. 08 Şubat 2021.

“Sugar cane production quantity” Knoema 2020. Web. 16 Mart 2021.

Türeyen, Suat. "Bir Biyoyakıt Olarak Etanol.” Gönder-Geleceği Önemseyenler Derneği. 2015. Web. 21 Haziran 2020

Uludüz, Özgür. "Biyo Yakıtlar: Brezilya Örneği." Dış İşleri Bakanlığı Yayınları Uluslararası Ekonomik Sorunlar Dergisi 25. (2007). Web. 01 Şubat 2021.

Ünlü, Derya. Fosil Yakıtlara Çevre Dostu Yenilenebilir Alternatif: "Biyoyakıtlar". Uluslararası Enerji Ekonomi ve Güvenlik Kongresi, Tam Metin Bildiriler Kitabı, 67 Nisan. Ed. Seyfettin Erdoğan, Ayfer Gedikli ve Durmuş Çağrı Yıldırım. İstanbul 2019. 30-39. 
Yıldırım, Oğuz ve Fatme İsmail Nuri "Yenilenebilir Enerji ve Sürdürülebilir Kalkınma İlişkisi” Journal of Internatıonal Bankıng Economy And Management Studies 1.1(2018): 105-143.

Y1lmaz, Mutlu.“Türkiye'nin Enerji Potansiyeli ve Yenilenebilir Enerji Kaynaklarının Elektrik Enerjisi Üretimi Açısından Önemi.”Ankara Üniversitesi Çevre Bilimleri Dergisi 4.2.(2012): 33-54.

"Wind Energy". Internationa Renewable Energy Agency (IRENA), 2020. Web. 23 Şubat 2021.

"Wind Energy in Brazil is Expected to Have 24.2 GW by 2024."Evwind, 2020. Web. 07 Ekim 2020.

\section{Summary}

Energy is the core of our civilization. Without it, technological developments cannot be achieved. Fossil fuelsare predominant energy sources especially from the beginning of the 20th century. But on the other hand fossil fuels give harm to the nature. Because of that fact world is trying to find alternate energy sources.With the increasing speed of harm of fossil fuels, future generations will face lots of difficulties. Renewable energy sources are good alternatives. Because they do not give harm to the nature. Besides theyare not onlyadvantageous in stooping climate change but also they are interminable. Since the fossil fuels are not interminable they may cause wars. But renewable sources are interminable and all countries somehow have got a kind of renewable sources. This reduces the possibility of waging wars for the cause of energy crisis. In that extend renewable energy sources have got lots of advantages than fossil fuels. But world can not just start to use these sources with an eye blink. Still we have got a high energy dependance on fossil fuels. But it must changein the future in favor of our world and our children.

Latin American countries are developing economies. There are big Latin American economies like Brazil, Mexico and Argentina. They are trying to develop their technologies. Forthis reason they need energy. But Latin America has got big renewable energy opportunities. Each country has got big opportunities of solar, hydro, wind, biomass and geotermal energy. Brazil is the biggest economy among Latin American countries. And it is the one which needs energy the most. But also Brazil is the biggest country of South America continent. The country has got diffirent climates, flora and animals within its boarders. The country also has got lots of natural sources. It gives a very big advantage to Brazil. Since Brazil is a very 
big growing economy, renewable energy is a very good option for the country. The natural sources give Brazil a big play ground to have big renewable energy investments. Especially hydro energy is very strong in Brazil. The Amazon Basin has got very powerful rivers which enable to set up high capacity hydropower dams. Brazil produces a big portion of its energy from its powerful hydro energy dams. Besides, Brazil is a big agriculture country. Sugar cane production has got a historical importance in Brazil's economy. Today this importance has got another aspect because of bio mass energy usage. Ethanol, produced form bio mass, is used as an energy source. Especially, ethanol mixture of gasoline is highly used as car fuel. There are hybrid cars which use that green friendly mixture. This not only decreases petrol dependance but also gives less harm to the environment. Brazil is from one of the biggest ethanol producers and consumers in the world. It is also a very good example for other nations. Because environmental concerns will save the future of our children. Apart from hydro power and bio mass, Brazil also enjoys of using solar energy and wind power. Important investments are realized and the country ventures to make further investments to get more use of these kind of renewable energies.

To sum up, it is evident that energy dependance is vital in today's world due to technological developments. In the future there will be more technological developments and for this reason we can think that we will need more energy. Today'sworld is dominated by fossil energy resources. But these resources are very dangerous for our nature. Renewable energy is a very good alternative since they do not give as much harm as fossil fuels and besides they are interminable. World countries faced this reality and they started to use more renewable energy. Latin American countries with their growing economy are also aware of this reality. Brazil is the biggest economy in Latin America and it needs more energy. Having big natural resources Brazil gets use of them and has got important investments in renewable sources and it seems that it will have more investments in the future. Like how Brazil does, we need to realize more investments to renewable energy because we are going to need more energy in the future and a better, not polluted nature. 